\title{
SOCIAL-ECOLOGICAL RESPONSIBILITY OF BUSINESS: ESSENCE, FACTORS OF FORMATION, MANIFESTATION CHARACTERISTICS
}

\author{
Natalya I. Matova \\ Branch of Institute of Natural and Technical Systems, Sochi, Russian Federation
}

\author{
Svetlana I. Mishulina \\ Sochi Scientific Research Center of the Russian Academy of Science, Sochi, Russian Federation
}

\begin{abstract}
As a result of studying the nature of socio environmental responsibility of business (SER) and associated concepts, the transformation of its content with the experience gained and also with the evolution of society and its expectations during the investigation of different SER levels being formed successively and urgent at the given moment, it is stated that business responsibility falls outside the scope of duties set by society and formalized minimum requirements, it voluntarily (to some extent) accepts rather high obligations in order to cut negative impacts of the decisions and actions on nature and as a result on society. These motives are not in conflict with the main business function - profit maximization because it is defined by necessary strategic vision of risks resulted from business activity and from the transformation of social goals and values as well as of the development of the environment for sustainable functioning and stable profit in future ("reasonable selfishness" concept). The classification and grouping of Russian business entities based on the motive of social responsibility are suggested. Institutional, economic and organizational factors as well as conditions for SER of business growth are defined and the instruments of state and public effect on business SER development processes are defined.
\end{abstract}

Key words: socio-environmental responsibility, corporate citizenship, motivation, environmental consciousness, values.

Citation. Matova N.I., Mishulina S.I. Social-Ecological Responsibility of Business: Essence, Factors of Formation, Manifestation Characteristics. Journal of Volgograd State University. Economics, 2020, vol. 22, no. 3, pp. 123-137. (in Russian). DOI: https://doi.org/10.15688/ek.jvolsu.2020.3.11

\section{СОЦИАЛЬНО-ЭКОЛОГИЧЕСКАЯ ОТВЕТСТВЕННОСТЬ БИЗНЕСА: СУЩНОСТЬ, ФАКТОРЫ ФОРМИРОВАНИЯ, ОСОБЕННОСТИ ПРОЯВЛЕНИЯ}

\author{
Наталья Ивановна Матова \\ Институт природно-технических систем (филиал), г. Сочи, Российская Федерация \\ Светлана Ивановна Мишулина \\ Сочинский научно-исследовательский центр РАН, г. Сочи, Российская Федерация
}

Аннотация. В результате исследования сути социально-экологической ответственности (далее-СЭО) и
смежных понятий, трансформации ее содержания как в результате приобретенного опыта, так и с изменени-
ем общества и его ожиданий в ходе изучения различных уровней СЭО, формировавшихся последовательно
и актуальных на данный момент, в работе констатируется выход ответственности бизнеса за рамки обязанно-
стей (установленных обществом и формализованных минимальных требований), добровольное (в той или
иной степени) принятие на себя повышенных обязательств в отношении сокращения негативных послед-
ствий своих решений и действий для природной среды и, как следствие, общества. Мотивация такой деятель- 
ности не противоречит основной функции бизнеса - максимизации прибыли, так как определяется необходимостью стратегического видения, возникающих в результате как деятельности фирмы, так и трансформации целей и ценностей общества, рисков и формирования сегодня условий для устойчивого функционирования и получения стабильной прибыли в будущем (концепция «разумного эгоизма»). Дана классификация и соответствующая ей группировка российских компаний в зависимости от мотивов проявления ими социальной ответственности. Обозначены институциональные, экономические и организационные факторы и условия повышения СЭО бизнеса, определены инструменты государственного и общественного воздействия на процессы формирования СЭО бизнеса.

Ключевые слова: социально-экологическая ответственность, корпоративное гражданство, мотивация, экологическое сознание, ценности.

Цитирование. Матова Н. И., Мишулина С. И. Социально-экологическая ответственность бизнеса: сущность, факторы формирования, особенности проявления // Вестник Волгоградского государственного университета. Экономика. - 2020. - Т. 22, № 3. - C. 123-137. - DOI: https://doi.org/10.15688/ek.jvolsu.2020.3.11

\section{Введение}

Активное формирование концепции СЭО началось в 70-80-х гг. XX века. Сложность категорий, отражающих сущность концепции, ее междисциплинарный характер, включающий философские, социологические, психологические, экономические, экологические и др. аспекты, до сих пор определяет остроту научных дискуссий и является причиной отсутствия общепринятого понятийного аппарата. Дискуссии ведутся как в области определения сущности, факторов и условий формирования социальной ответственности бизнеса, так и с целью выявления характеристик ожидаемых, признаваемых и приветствуемых обществом форм ее проявления, определяя актуальность исследований в этой сфере.

Несмотря на продолжающиеся споры теоретиков, концепция социальной ответственности так или иначе формализуется в международных и национальных нормативно-правовых актах (стандартах) и все больше находит свое приложение в практической деятельности как некоммерческих, так и коммерческих организаций. В то же время суть и содержание самой концепции претерпевает трансформацию как на основе полученного опыта, так и с развитием общества и его ожиданий.

Целью данной работы явилось исследование современных подходов к определению сути СЭО и смежных понятий, трансформации ее содержания при переходе на новые уровни развития, формировавшиеся последовательно под воздействием различных факторов и актуальных на данный момент. В свою очередь, понимание сути СЭО, закономерно- стей и условий ее формирования позволяет найти эффективные инструменты государственного и общественного стимулирования повышения СЭО бизнеса.

\section{Понятие и содержание категории «социально-экологическая ответственность»}

В нашей стране существует распространенное представление, сложившееся и на основе дореволюционной практики меценатства в России [Хорева и др., 1999; Рушева, 2019] и на примерах новейшей истории, что основная форма проявления социальной ответственности бизнеса - это участие, выражаемое в различных формах (финансовое, организационное, другими ресурсами) в социально значимых проектах в сферах, как правило, не связанных с основной деятельностью компании. Развивая эту идею, И.А. Минина, например, предлагает в отношении корпоративной социальной ответственности «под компанией понимать лиц, принимающих решения о распределении прибыли и, в частности, о направлении полученной прибыли для осуществления программ социальной поддержки» [Минина, 2009]. В современной теории этот подход, предполагающий соблюдение установленных норм в сочетании с благотворительностью, получил название концепции «корпоративного альтруизма» [Никифорова и др., 2017].

Новый взгляд на сущность социальной ответственности был зафиксирован в 2010 г. в Международном стандарте ИСО 26000 [ГОСТ Р ИСО 26000-2012 ...], в котором социальная ответственность представлена как 
ответственность организации за воздействие ее решений и деятельности на общество и окружающую среду, она проявляется через прозрачное и этичное поведение, которое содействует устойчивому развитию, включая здоровье и благосостояние общества. В числе семи направлений, или сфер, в которых может и должна проявляться социальная ответственность организаций, выделяется направление «Окружающая среда». В соответствии с принятым стандартом определением (не очень, на наш взгляд, корректным, поскольку ответственность определяется ответственностью же) ответственность проявляется через конкретный набор и алгоритм действий, включающий в качестве обязательных составляющих анализ целей и средств их реализации, разработку стратегии гармонизации социальных, экологических и экономических целей бизнеса с целями и ценностями общества, оценку последствий деятельности и разработку механизмов минимизации негативных ее последствий (поиск инновационных решений), аудит, контроль и корректировку стратегий и планов.

Ключевым моментом данного определения, на наш взгляд, является четкое разграничение добровольного участия фирмы в благотворительных и других социально значимых проектах и акциях, не связанных с еe деятельностью и ответственностью за решения и действия фирмы, имеющие экологические и обусловленные ими социальные последствия. В соответствии с этим подходом нельзя считать социально ответственной фирму, которая в ходе своей деятельности оказывает негативное воздействие на окружающую среду (например, осуществляя недостаточно очищенные сбросы и выбросы или нерационально используя энергетические, водные и др. ресурсы, уничтожая целые биотопы в ходе реализации планов по расширению своей деятельности), но в целях получения некой общественной индульгенции проводит акции по высадке деревьев.

Анализ существующих подходов отечественных и зарубежных ученых и специалистов, а также терминологии и основных положений стандарта ИСО 26000 позволяет предложить следующее определение социальной ответственности в отношении окружающей природной среды: СЭО - добровольно взятая на себя обязанность отвечать перед заинтересованными сторонами и обществом в целом за решения и действия, а также их последствия для природной среды как на территории присутствия, так и в планетарном масштабе, которое проявляется через прозрачное и этичное поведение, интегрировано в деятельность всей организации, соответствует стратегическим целям ее развития и применяется во всех взаимоотношениях [Mатова, 2019а]. Реализуется СЭО через выбор средств достижения целей бизнеса, основанный на оценке экологических и обусловленных ими социальных последствий и соответствующий установившейся в обществе системе целей и ценностей.

Уровень мотивации социально-экологической ответственности в значительной мере определяется формальной и неформальной институциональной средой, сформировавшейся как в целом в стране, так и на территории осуществления хозяйственной деятельности. Спектр мотивации к СЭО достаточно широк, однако основные мотивы можно сгруппировать в 5 основных блоков, приведенных в таблице. Представленные в таблице группы характеризуются также социальными и экономическими институтами, формирующими и стимулирующими социально-экологически ответственное поведение бизнеса с использованием различных механизмов, свойственных и доступных им.

Процентное соотношение компаний, руководствующихся различными мотивами социально-экологически ответственного поведения, в соответствии с результатами исследования [Ценностные основы ..., 2015], проведенного в 2014 г., выглядит следующим образом:

- корпоративные требования (первая группа таблицы) -8 \% крупных российских и $10 \%$ иностранных компаний. Компании среднего и малого бизнеса этот мотив не озвучили;

- повышение значимости бренда (четвертая группа таблицы) - 8 \% крупных российских и $13 \%$ иностранных компаний. Для малого и среднего бизнеса неактуально;

- общественные ценности (пятая группа таблицы): традиции компании - 27 \% крупных российских и $16 \%$ иностранных компаний; семейные традиции - компании среднего 
и малого бизнеса $16 \%$ и $20 \%$, соответственно; религиозные мотивы - $7 \%$ среднего и $18 \%$ малого бизнеса, ни одного респондента крупного бизнеса;
- личные ценности (шестая группа таблицы) - 35 \% крупных российских, 32 \% иностранных компаний, 28 \% компаний среднего и малого бизнеса (см. таблицу).

\section{Классификация и группировка субъектов российского бизнеса, институтов и механизмов формирования их социально-экологической ответственности по признаку «мотивы проявления социальной ответственности»}

\begin{tabular}{|c|c|c|c|c|}
\hline $\begin{array}{c}\text { № } \\
\text { II/II }\end{array}$ & $\begin{array}{c}\text { Мотивы проявле- } \\
\text { ния социально- } \\
\text { экологичес-кой } \\
\text { ответственности }\end{array}$ & $\begin{array}{l}\text { Институть, формирующие } \\
\text { социально-экологи ческую } \\
\text { ответственность бизнеса }\end{array}$ & $\begin{array}{c}\text { Механизмы формирования } \\
\text { социально-экологической } \\
\text { ответственности бизнеса }\end{array}$ & $\begin{array}{c}\text { Tипичные представители } \\
\text { бизнеса данной группы }\end{array}$ \\
\hline 1 & $\begin{array}{l}\text { Обеспечение со- } \\
\text { ответствия тре- } \\
\text { бованиям и за- } \\
\text { просам ино- } \\
\text { странных вла- } \\
\text { дельцев, партне- } \\
\text { ров и инвесторов }\end{array}$ & $\begin{array}{l}\text { Международные фор- } \\
\text { мальные и неформальные } \\
\text { правила и практики веде- } \\
\text { ния бизнеса }\end{array}$ & $\begin{array}{l}\text { Стандартизация (продук- } \\
\text { ции и процессов). } \\
\text { Сертификация (продук- } \\
\text { ции, процессов, организа- } \\
\text { ции). } \\
\text { Экологический аудит } \\
\text { ОВОС при разработке } \\
\text { проектов развития }\end{array}$ & $\begin{array}{l}\text { Подразделения трансна- } \\
\text { циональных компаний. } \\
\text { Компании с иностранным } \\
\text { капиталом и/или менедж- } \\
\text { ментом. } \\
\text { Компании, оперирующие } \\
\text { на международном рынке и } \\
\text { находящиеся в сфере меж- } \\
\text { дународной конкуренции }\end{array}$ \\
\hline 2 & $\begin{array}{l}\text { Обязанность в со- } \\
\text { ответствии с рос- } \\
\text { сийским законо- } \\
\text { дательством }\end{array}$ & $\begin{array}{l}\text { Государство, в том числе } \\
\text { под влиянием междуна- } \\
\text { родных организаций, про- } \\
\text { ектов, программ в области } \\
\text { экологии и устойчивого } \\
\text { развития }\end{array}$ & $\begin{array}{l}\text { Законодательное регули- } \\
\text { рование. } \\
\text { Система контрольно- } \\
\text { надзорных органов. } \\
\text { Финансирование (бюд- } \\
\text { жетное) }\end{array}$ & $\begin{array}{l}\text { Государственные корпо- } \\
\text { рации, доля участия } \\
\text { в которых государства со- } \\
\text { ставляет } 100 \text { \%. } \\
\text { Компании с государ- } \\
\text { ственным участием }\end{array}$ \\
\hline 3 & $\begin{array}{l}\text { Допуск на рынок } \\
\text { ценных бумаг }\end{array}$ & $\begin{array}{l}\text { Органы и учреждения, } \\
\text { осуществлявшие ре- } \\
\text { гулирование рынка цен- } \\
\text { ных бумаг в России и в } \\
\text { мире, в том числе под } \\
\text { влиянием государства и } \\
\text { международных практик } \\
\text { рынка ценных бумаг }\end{array}$ & $\begin{array}{l}\text { Процедуры допуска на } \\
\text { рынок ценных бумаг }\end{array}$ & $\begin{array}{l}\text { Акционерные общества, } \\
\text { ценные бумаги которых } \\
\text { допущены к организо- } \\
\text { ванным торгам. } \\
\text { Участники рынка ценных } \\
\text { бумаг }\end{array}$ \\
\hline 4 & $\begin{array}{l}\text { Экономические } \\
\text { преимущества } \\
\text { социально-эколо- } \\
\text { гической ответ- } \\
\text { ственности }\end{array}$ & $\begin{array}{l}\text { Ответственное потребле- } \\
\text { ние. } \\
\text { Конкуренция. } \\
\text { Отраслевое и территори- } \\
\text { альное сотрудничество } \\
\text { (обмен «лучшими практи- } \\
\text { ками») }\end{array}$ & $\begin{array}{l}\text { Система природоохранных } \\
\text { платежей. } \\
\text { Распространение инфор- } \\
\text { мации и стимулирование } \\
\text { внедрения ресурсосбере- } \\
\text { гающих технологий. } \\
\text { Гудвилл (деловая репута- } \\
\text { ция) }\end{array}$ & $\begin{array}{l}\text { Новые компании с про- } \\
\text { грессивным менеджмен- } \\
\text { том }\end{array}$ \\
\hline 5 & \begin{tabular}{l}
\multicolumn{2}{l}{ Соответствие } \\
ожиданиям об- \\
щества или кон- \\
кретного значи- \\
мого сообщества
\end{tabular} & $\begin{array}{l}\text { Традиции (бизнеса, семьи, } \\
\text { национальные). } \\
\text { Общественное мнение. } \\
\text { Религия }\end{array}$ & $\begin{array}{l}\text { Пропаганда идеи от- } \\
\text { ветственности бизнеса. } \\
\text { Формулировка и публич- } \\
\text { ное высказывание ожида- } \\
\text { ний обществом. } \\
\text { Защита обществом своих } \\
\text { интересов }\end{array}$ & $\begin{array}{l}\text { Семейный бизнес. } \\
\text { Компании с с длительной } \\
\text { историей. } \\
\text { Компании, связывающие } \\
\text { свою деятельность с терри- } \\
\text { торией с сильным тради- } \\
\text { ционным укладом жизни }\end{array}$ \\
\hline 6 & $\begin{array}{l}\text { Внутренняя убе- } \\
\text { жденность собст- } \\
\text { венников, руко- } \\
\text { водства в своей } \\
\text { ответственности } \\
\text { за состояние при- } \\
\text { роды }\end{array}$ & $\begin{array}{l}\text { Семья. } \\
\text { Образование. } \\
\text { Наука. } \\
\text { Общество. } \\
\text { Религия }\end{array}$ & $\begin{array}{l}\text { Воспитание. } \\
\text { Просвещение. } \\
\text { Информирование. } \\
\text { Обучение }\end{array}$ & $\begin{array}{l}\text { В основном - субъекты } \\
\text { креативной экономики } \\
\text { (сектор экономики, осно- } \\
\text { ванный на интеллектуаль- } \\
\text { ной деятельности, проект- } \\
\text { ном мышлении, креатив- } \\
\text { ном воображении и прак- } \\
\text { тической направленности) }\end{array}$ \\
\hline
\end{tabular}

Примечание. Составлено автором. 


\section{Уровни социально-экологической ответственности бизнеса. Базовый уровень}

Анализ современных взглядов на суть и содержание социально-экологической ответственности бизнеса [Матова, 2019б], нашедших отражение в научной и методической литературе [Лабаджян и др., 2014; Ускова и др., 2016; ГОСТ Р ИСО 26000-2012 ...], позволяет выделить три ее уровня: базовый, первый и второй.

Базовый уровень - соблюдение норм законодательства (природоохранного, налогового, трудового и др.). Многие авторы считают, что социально-экологическая ответственность обусловлена требованиями законодательства, а в условиях его постоянного ужесточения необходимостью обеспечить безболезненную адаптацию к таким ужесточениям в будущем. С нашей точки зрения, в таком подходе присутствует некоторая подмена понятий. Соблюдение любого, в том числе природоохранного, налогового и трудового (социального) законодательства, является обязательным условием допустимости хозяйственной деятельности, независимо от того, берет ли бизнес на себя добровольную социально-экологическую ответственность или нет. Нарушение законов предполагает неизбежные санкции, вплоть до прекращения деятельности. При этом, если под ответственностью понимать соблюдение законодательства в условиях, когда есть возможность его не соблюдать (при слабых институтах принуждения), такая точка зрения вполне оправдана. Сегодня, в условиях отсутствия внутренней убежденности в необходимости экологически ориентированного изменения модели производства и потребления, обычной реакцией на ужесточение законодательных норм становится поиск не путей снижения негативного воздействия на окружающую природу, а вариантов безнаказанного нарушения законодательства. Бизнес и население стремятся скрыть реальные объемы своего негативного воздействия, а государство искажает оценки эффективности деятельности институтов, призванных обеспечить рациональное природопользование и охрану окружающей среды, законодатели формируют нормативно-правовую базу, противоречивую и изобилующую неоднозначными трактовками, создающую институциональные ловушки [Бондаренко и др., 2019].

Базовый уровень, по сути, соответствует довольно широко используемому в юриспруденции и прикладной экономике понятию «экологическая ответственность», под которой понимается экономико-правовой комплекс, содержащий в себе нормы и соответствующие им отношения по возмещению и предупреждению вреда природной среде [Матова, 2019а]. Экологическая ответственность в данной трактовке имеет, соответственно, две формы: экономическую и юридическую (правовую). Первая из них, эколого-экономическая ответственность связана с правомерной деятельностью, появляется в связи с нанесением в ее результате вреда и при наличии причинной связи между характером экономической деятельности и возникшим ущербом природной среде, например, в виде возмещения потерь от лесохозяйственного производства, платы за использование вод в промышленности и сельском хозяйстве, за размещение отходов и др. Эколого-правовая (юридическая) ответственность, в свою очередь, представляет собой обязанность претерпевать неблагоприятные последствия за совершенное экологическое правонарушение в соответствии с предусмотренными санкциями нарушенной нормы права. Часто и в публицистических материалах, и в научных исследованиях понятие «экологическая ответственность» приравнивают к ответственности за экологические правонарушения [Иванов, 2015].

Важным условием реализации базового уровня является экологическая ответственность государства, то есть последовательное и неукоснительное исполнение буквы и духа природоохранного законодательства, а также государственных программ и стратегий в области природопользования и охраны окружающей среды со стороны органов власти (законодательной, исполнительной, судебной) и субъектов государственного сектора экономики. К сожалению, следует признать наличие фактов их оппортунистического поведения ${ }^{1}$, когда в угоду краткосрочной экономической эффективности, соблюдения сроков или иных условий реализации государственных проек- 
тов нарушается если не буква, то дух законов, регулирующих природопользование. Яркий пример попрания декларируемых экологических приоритетов - проблемы с соблюдением интересов окружающей природной среды при реализации национального проекта XXII зимних Олимпийских игр в Сочи. Ключевые олимпийские объекты горного кластера оказались на заповедной территории Сочинского национального парка, в границах особо охраняемой зоны с режимом заказника, что нарушало федеральное законодательство (Ф3 «Об особо охраняемых природных территориях», Земельный кодекс РФ, ФЗ «Об охране окружающей среды» и др.), а также противоречило обязательствам, декларированным в «Заявочной книге Сочи - 2014». Решением проблемы стал не перенос месторасположения олимпийских объектов, а отмена или изменение законов или их отдельных правовых норм, что привело к массированному хозяйственному вторжению на эти уникальные территории с последующей деградацией их экосистем, разрушением ландшафтов, активизацией опасных геологических процессов [Бриних, 2014; Гудкова, 2017].

\section{Первый уровень}

\section{социально-экологической ответственности бизнеса}

Первый уровень (после базового, который, как отмечалось выше, является обязанностью компаний) СЭО - стремление организации учитывать экологические факторы в процессе принятия решений и быть подотчетной за воздействие своих решений и деятельности на окружающую среду [ГОСТ Р ИСО 26000-2012 ...]. Социально-экологическая ответственность, таким образом, должна быть интегрирована в основную деятельность компании, ее систему управления и схему взаимоотношений для предотвращения или минимизации негативного воздействия деятельности компании и производимого ею продукта на природную среду, принимая во внимание воздействие всего жизненного цикла используемых в деятельности ресурсов и технологий. Или, как подчеркивают Л. Престон и Дж. Пост: «Фирма ответственна за те проблемы, которые сама порождает, которые связа- ны с ее деятельностью и затрагивают ее интересы» [Благов, 2011].

Социально-экологическая ответственность на данном уровне - «добровольная разработка программ и мероприятий, выходящих за рамки законодательства в сфере охраны окружающей среды, и их реальное осуществление» [Губарева и др., 2011] с целью сокращения негативных экологических и обусловленных ими социальных эффектов деятельности фирмы. В этом плане совершенно оправдан, с нашей точки зрения, подход некоторых авторов, считающих, что СЭО не заменяет законодательство и государственное регулирование, а способствует ликвидации пробелов и институциональных ловушек в этой сфере, является адаптированным к условиям данного бизнеса дополнением существующих норм и форм контроля [Нужина и др., 2017]. В качестве основных направлений, по которым организации необходимо выявлять аспекты воздействия своих решений и действий, а затем разрабатывать соответствующие программы, можно выделить следующие: предотвращение всех форм загрязнения - воды, атмосферы, почвы, в том числе в результате обращения с отходами; устойчивое ресурсопользование, приоритет - в отношении энергии; сохранение и восстановление биоразнообразия и природных мест обитания, особенно актуально при проектировании новой и расширении существующей деятельности. В стандарте ИСО 26000 подчеркивается: «Организации следует сосредоточиться на инновациях, а не только на соблюдении законодательства и нормативных требований, а также следует поставить себе целью непрерывное повышение своей экологической результативности» [ГОСТ Р ИСО 26000-2012 ...].

Экологически ответственный бизнес, по сути, представляет собой «зеленую» экономику с точки зрения технологического подхода к ней, то есть как к экономике, которая базируется на применении «чистых» ресурсосберегающих технологий, снижающих риск адекватного негативного ответа природы на потребительское поведение человека [Мишулина, 2016]. Отличительная черта субъектов зеленой экономики заключается в том, что при выборе варианта действий они принимают и осознанно применяют в своей деятельности 
ограничения, накладываемые соображениями сохранения целостности и невредимости окружающей природной среды [Матова, 2016]. Таким образом, цель как субъектов зеленой экономики, так и социально-экологически ответственного бизнеса заключается не только в максимизации выгоды и минимизации затрат, но еще и в сокращении негативного воздействия на окружающую природную среду всех этапов жизненного цикла продукта и производства.

Развитие концепции СЭО с момента ее международной формализации (2010 г.) сопровождается дискуссией в научной и профессиональной литературе о роли социальной ответственности бизнеса в обеспечении устойчивого экономического развития и роста компании как одного из способов повысить ее конкурентоспособность на долгосрочной основе. Наибольшую поддержку среди исследователей и специалистов получила идея разделяемой (общей) ценности (shared value), выдвинутая М. Портером и М. Креймером [Porter et al., 2011]. Основной ее посыл заключается в том, что бизнес, действующий по собственной (экономической) модели, а не как донорблаготворитель, является реальной силой, способной решить существующие (социальные и экологические) проблемы. Авторы подчеркивают, что, с одной стороны, «несовершенство общества или социальное (и экологическое. H. M., C. M.) неблагополучие зачастую становится источником внутренних издержек корпорации». С другой стороны, «решение проблем и преодоление ограничений, возникающих вследствие несовершенства общества, не всегда влекут за собой увеличение расходов, так как компании могут использовать инновационные подходы, основанные на технологиях, новых методах работы и управленческих практиках, которые в итоге позволяют повысить производительность и расширить рынки сбыта» [Porter et al., 2011].

Главное изменение, по мнению М. Портера и М. Креймера, должно коснуться миссии бизнеса и его маркетинговой идеологии зарабатывать не на проблемах общества, а решая его проблемы. Центральное место в стратегии компаний должно отводиться общественно значимой цели, что означает строить бизнес на удовлетворении действительных, объективно существующих потребностей общества, соответствующих истинным ценностям, имеющимся и формируемым совместно с обществом.

Речь идет о направлении ресурсов (финансовых, управленческих, маркетинговых, исследовательских) на стратегическое решение первопричин социальных и экологических проблем, что будет способствовать качественному росту благополучия всех заинтересованных сторон (местных и глобальных сообществ, природной среды, всех участников цепочки создания стоимости), что, в свою очередь, обеспечит устойчивый спрос, снижение издержек и следовательно стоимости продукта за счет повышения эффективности на всей цепочке его создания и во вспомогательных производствах, а также улучшит деловую, социальную и экологическую среду деятельности компании, тем самым снизит некоторые внутренние издержки производства.

Концепция общей (разделяемой) ценности корреспондирует с понятием «социальное предпринимательство», которое появилось в специализированной литературе в 1960-1970-х гг, а широкое распространение получило начиная с 2000-х гг. и в то же время до сих пор не имеет четкого и однозначно трактуемого определения своего содержания. Анализ существующих определений показал, что общим для них является представление социального предпринимательства в виде коммерческих структур, решающих социальные проблемы в ходе своей основной деятельности [Гришин и др., 2015], при этом критериальное свойство - приоритетность не максимизации прибыли, а выполнения определенной социальной миссии [Зайнашева и др., 2018].

Нам видится некоторая искусственность и внутренняя противоречивость данного понятия. С одной стороны, провозглашение приоритетности социальной или экологической миссии перед целью получения прибыли сразу исключает такой вид деятельности из сферы собственно предпринимательства и относит организацию к разряду НКО, имеющей право заниматься предпринимательской деятельностью для достижения уставной цели в случае, если доходы от нее не перераспределяются между членами или участниками этих объединений (ст. 37 Федерального закона от 
19.05.1995 № 82-Ф3 «Об общественных объединениях»). С другой стороны, если основным критерием социального предпринимательства считать добросовестность предпринимателя, этичность его деятельности и предпринимаемые усилия для решения или смягчения существующих социальных или экологических проблем, мы имеем дело с социально ответственным бизнесом. Деятельность социально ответственного бизнеса, основанного на разделяемой (общей) ценности, более всего похожа на образ социального предпринимательства, но в этих концепциях есть принципиальная разница - в первом случае целью остается прибыль, а решение социальной проблемы встроено в технологические, маркетинговые, управленческие бизнес-процессы компании.

В качестве примера бизнеса, действующего на основе разделяемой (общей) ценности в нашей стране, можно назвать появляющиеся повсеместно компании, осуществляющие переработку отходов и утилизацию отсортированных материалов. В большинстве своем учредители и управляющие этих компаний занимаются данным видом деятельности, движимые осознанием насущности экологических проблем, вызываемых катастрофическим количеством отходов, складируемых на свалках и полигонах ТБО. Актуальность задачи, объективность ее существования еще достаточно длительное время, а также растущая социальная поддержка современных технологичных подходов к обращению с отходами создают устойчивую экономическую базу для коммерчески успешной деятельности в области переработки отходов и утилизации отсортированных материалов. Общая ценность начинает формироваться на исходном этапе цепочки создания стоимости - раздельного сбора бытовых отходов (далее - РСО), который осуществляется в первую очередь домохозяйствами. Сегодня основная роль в пропаганде и осуществлении РСО принадлежит некоммерческим общественным движениям и организациям, таким как НКО Ассоциация в сфере экологии и защиты окружающей среды «РазДельный Сбор» и его проекту «Экодвор», общественный проект «Теперь так», межрегиональная экологическая общественная организация «ЭКА» и другим.

\section{Второй уровень социально-экологической ответственности - корпоративное гражданство}

Второй уровень СЭО предполагает, помимо обязательного соответствия характеристикам первого уровня, еще и благотворительную деятельность, спонсорство, то есть добровольный вклад в экологические проекты, которые не связаны напрямую с деятельностью компании. Важно подчеркнуть, что действительно социально и экологически значимой является филантропия только компаний, прилагающих усилия по минимизации отрицательного воздействия на природу и общество своих действий и решений. Как отмечает стандарт ИСО 26000, «филантропия (в этом контексте понимаемая как пожертвования на благотворительные цели) может оказывать позитивное воздействие на общество. Однако организациям не следует ее использовать в качестве замены интеграции социальной ответственности в рамки организации» [ГОСТ Р ИСО 26000-2012 ...].

Это уровень вполне соответствует понятию «корпоративное гражданство». Ряд исследователей, в том числе И. Божко [Божко], разделяет понятия «корпоративное гражданство» и «корпоративная социальная ответственность», и основное различие заключается, по их мнению, в том, что деятельность компании как корпоративного гражданина связана с участием в решении широкого спектра социальных и экологических проблем, в то время как социально ответственный бизнес нацелен на нивелирование проблем, создаваемых деятельностью самой компании и ее продукта. Мы считаем, что это разные эволюционные уровни одного явления, при этом важно, что более высокий уровень предполагает исполнение обязательств всех предыдущих ступеней.

Критериальным свойством корпоративного гражданства считается также присутствие компании в социально-политическом пространстве, наличие у нее последовательной позиции по ключевым вопросам публичной политики, влияющим как на бизнес, так и на общество в целом. В силу последнего утверждения считается, что уровень корпора- 
тивного партнерства доступен исключительно крупным компаниям, значительным игрокам национального и мирового рынков: «Экономическая мощь, накопленный человеческий капитал, глобальный масштаб деятельности и колоссальная степень влияния на социум позволяют ТНК принимать непосредственное участие в его развитии» [Матвеева, 2014]. При этом проявлять себя в пространстве публичной политики, понимаемой как проявление и согласование общественных интересов, можно и на местном уровне. Таким образом, средний и даже малый бизнес вполне может быть корпоративным гражданином локального уровня, совместно с представителями гражданского общества и муниципалитетом формировать ценности и основанные на них решения, способные обеспечить устойчивое развитие территории и защиту интересов стейкхолдеров, а также внедрять эти ценности в свое корпоративное управление.

Возвращаясь к таблице, можно констатировать, что большинство компаний, относящихся ко второй, третьей и даже первой группам по признаку «мотив проявления социальной ответственности», находятся лишь на базовом уровне социальной ответственности, которая по существу является формальным исполнением отдельных требований законодательства или правил международной деловой практики. Интеграция социальной ответственности в систему управления носит имитационный характер: при наличии на бумаге соответствующих политик, сертифицированных систем менеджмента, программ обучения персонала, публикуемой нефинансовой отчетности происходит одновременное осуществление антисоциальной и разрушительной для окружающей природной среды деятельности. В своей практике подобные организации учитывают ожидания заинтересованных сторон только до тех пор, пока они не мешают, а порой и помогают достижению интересов самой компании. Яркий пример - ОАО «РЖД», которое формально является «передовиком» социальной ответственности отечественного бизнеса: в 2006 г. в числе первых госкорпораций начало публикацию «Корпоративного социального отчета», в 2008 г. был утвержден «Кодекс корпоративной социальной ответственности ОАО “РЖД”», в котором корпора- тивная социальная ответственность представлена как «добровольный вклад в развитие государства, общества и бизнеса в экономической, социальной и экологической сферах, который напрямую связан с осуществлением хозяйственной деятельности ОАО “РЖД”». Однако на практике ОАО «РЖД» сегодня лоббирует и является участником проектов, несущих экологическую и социальную катастрофы для целых регионов нашей страны. Речь идет, в частности, о продвижении идеи создания так называемых межрегиональных «Экотехнопарков», которые, по сути, являются крупномасштабными полигонами утилизации отходов различных классов опасности, транспортировка которых до мест захоронения планируется осуществляться или осуществляется по железной дороге.

\section{Тенденции развития теории и практики социальной ответственности бизнеса}

Характерной чертой текущего этапа эволюции теории и практики социальной и экологической ответственности бизнеса является партнерство, которое проявляется на различных уровнях и направлениях:

- с заинтересованными сторонами, или стейкхолдерами, - частными лицами или группами, а также организациями, которые могут подвергать воздействию, подвергаться воздействию или считать, что подвергаются воздействию решений или деятельности данной организации [ГОСТ Р 56548-2015/ISO/DIS/ $37101 \ldots]$... Партнерское взаимодействие в этом аспекте происходит в ходе совместного поиска и определения конкретных проявлений взаимного влияния решений и деятельности компании, с одной стороны, и стейкхолдеров - с другой, в выявлении эффективных путей оптимизации данного влияния. Партнерство появляется в результате открытого диалога в различных форматах;

- в пределах так называемой «сферы влияния» организации, в первую очередь по цепочке создания стоимости, то есть среди поставщиков и потребителей товаров и услуг. Международный стандарт ИСО 26000 указывает, что организация может в некоторых ситуациях влиять на поведение организаций или сторон, с которыми она поддерживает взаи- 
моотношения или над решениями и деятельностью которых она осуществляет формальный или фактический контроль, например, в рамках формальных и неформальных ассоциаций, участником которых является, или даже через конкурентов. Привлечение компанией партнеров к деятельности по сокращению собственного негативного социально-экологического следа может осуществляться, например, путем внедрения системы ответственных поставок или привлечением контрагентов к формированию замкнутого цикла «производство потребление - утилизация»;

- межсекторальное, или «социальное партнерство», под которым традиционно понимаются партнерские (равноправные, взаимовыгодные) отношения государства, муниципалитетов, бизнеса и общества, направленные на решение социально значимых задач. В классическом трехсекторном взаимодействии «бизнес - государство - общество» происходит следующее «распределение ролей»: бизнес воспринимается как источник финансовых ресурсов, государство подключает организационные и административные ресурсы, некоммерческие организации предоставляют проекту человеческие ресурсы. Сегодня появляются примеры иного межсекторного взаимодействия, которые демонстрируют уход от традиционных схем, возникают новые сочетания вкладываемых в партнерские проекты ресурсов и функций [Хорева и др., 2015]. Практика последних десятилетий продемонстрировала ограниченность возможностей инструментов государственной социальной поддержки, корпоративной социальной деятельности и усилий некоммерческих организаций, применяемых по-отдельности, изолированно друг от друга [Благов]. У всех участников зреет убежденность, что ответить на сложные социальные и экологические вызовы современности возможно только сообща, совместно прилагая усилия, в различных формах и направлениях организуя взаимодействие государства, коммерческого и некоммерческого секторов, сообществ.

Рассматриваемый уровень - корпоративное гражданство, - подразумевает, что «бизнес не ждет, пока попросят, а ищет сам, куда и как направить свои социальные инвестиции, находит самые актуальные для общества темы и решает проблемы, волнующие большую часть населения» [Туркин, 2004]. Тем не менее перед компаниями зачастую встает вопрос: как получить объективную оценку социальной значимости заинтересовавшего проекта, особенно если он в сфере, не связанной с деятельностью организации и, соответственно, не знакомой ей. Более того, бизнес, вышедший на уровень корпоративного гражданства, стремится участвовать в проектах, нацеленных на системное решение проблемы, воздействующих на причины ее появления, а не ликвидировать локальные следствия социальных и экологических противоречий. В этих вопросах компании - корпоративные граждане опираются на знания, опыт и репутацию некоммерческих общественных организаций, сообществ и независимых экспертов, ведущих свою деятельность в выбранной для приложения усилий сфере, привлекая их в качестве консультантов и партеров [Матова, 2019б].

Важным современным трендом является институционализация корпоративной филантропии в виде создания корпоративных и частных фондов [Дегтярева и др., 2014], которые также охотно работают в партнерстве с НКО, так как они транслируют уже выявленное и обобщенное мнение некоторой части общества, которое сформировалось в ходе обсуждений и практической деятельности сообществ. Следует подчеркнуть, что ряд общественных экологических организаций, в числе которых можно назвать, например, Межрегиональную экологическую общественную организацию «ЭКА», отказывают в принятии предложений финансового и организационного участия в своих проектах, если они поступают от компаний, стремящихся таким образом имитировать социальную ответственность, пытаясь заменить усилия по уменьшению своего негативного воздействия на природу спонсорской помощью в социально значимых акциях и проектах.

\section{Выводы}

СЭО бизнеса предполагает добровольную деятельность, которая одновременно удовлетворяет требования экономической эффективности и экологической безопасности, то есть устраивает и фирмы, и общество: 
- фирмы получают возможность выбирать те формы снижения негативного воздействия на природную среду, которые способствуют росту их конкурентоспособности - за счет роста ресурсоэффективности и сокращения затрат в результате «зеленых» инноваций, повышения эффективности менеджмента, дифференциации собственной продукции и услуг на рынке, создания положительного имиджа, экологизации бренда, выхода на новые перспективные рынки;

- общество получает решение локальных, региональных и глобальных социальноэкологических проблем, появляется и тиражируется положительный опыт ответственного поведения бизнеса; целый ряд экологических и обусловленных ими социальных проблем сокращается за счет ответственного поведения бизнеса, высвобождая ресурсы на достижение тех общественных целей, которые лежат за пределами компетенции бизнеса.

Формирование социально-экологической ответственности бизнеса происходит под комплексным воздействием различных групп факторов, таких как:

- психологические-внутреннее понимание значимости сохранения природной среды и социального окружения как основы безопасной и комфортной жизнедеятельности (своей и будущих поколений);

- социальные - понимание общественной значимости природных активов и ресурсов, безопасной среды обитания и устойчивого развития; необходимость соответствовать общественным ожиданиям, целям и ценностям;

- экономические - основанные на знании о возможности повышения стратегической конкурентоспособности за счет применения наилучших доступных «зеленых» технологий, обеспечивающих снижение ресурсопотребления и, как следствие, затрат, а также соответствие растущему «зеленому» спросу;

- нормативно-правовые, включающие законодательно закрепленную социально-экологическую ответственность.

Каждый из них, в свою очередь, формируется применением различных методов и инструментов.

Уровень СЭО и законопослушности в вопросах природопользования в значительной мере определяется сформированностью экологичес- кого сознания, экологической грамотности и культуры населения. В этих условиях единственным реально действующим мотивом СЭО становится внутренняя убежденность субъектов природопользования (бизнеса, чиновников, населения) в необходимости сохранения природы как условия выживания человечества как вида, сохранения природного и культурного национального наследия как условия национальной идентификации. Подобная мотивация формируется и развивается в результате осознанных целенаправленных действий, обеспечивающих высокий уровень информированности субъектов природопользования о возможных экологических и связанных с ними социальных эффектах деятельности (или бездеятельности) и альтернативных - экологически дружественных моделях природопользования (производственного и потребительского поведения).

Решение этой задачи, в силу ее общественного характера, ложится в первую очередь на государственные институты, ответственные за образование и воспитание, в том числе собственным примером. Задачи применения широкого спектра информационных механизмов и инструментов как со стороны государства, так и со стороны делового сообщества - ликвидация недостатка или отсутствия информации о последствиях экологической безответственности всех действующих лиц в разных видах хозяйственной деятельности; донесение знаний о финансовых, технологических, маркетинговых и других выгодах внедрения «зеленых» технологий и практик (создание «банка лучших практик»); информирование о стратегических последствиях экологизации потребительского поведения.

\section{ПРИМЕЧАНИЕ}

${ }^{1}$ Оппортунистическое поведение определяется О. Уильямсоном, который ввел это понятие в научный оборот, как «преследование собственного интереса, доходящее до вероломства».

\section{СПИСОК ЛИТЕРАТУРЫ}

Благов, Ю. Е. Корпоративная социальная ответственность: эволюция концепции / Ю. Е. Благов. - 2-е изд. - СПб. : Высшая школа менеджмента, 2011. -272 с. 
Благов, Ю. Е. От CSR 1.0 к CSR 2.0. Sustainable Business / Ю. Е. Благов. - Электрон. текстовые дан. Режим доступа: http://csrjournal.com/7077blagov-yuriy-evgenevich-ot-csr-10-k-csr-20.html (дата обращения: 09.02.2020). - Загл. с экрана.

Божко, И. Корпоративное гражданство как составляющая устойчивого развития бизнеса и региона / И.Божко // Устойчивый бизнес, 24.09.2015. - Электрон. текстовые дан. - Режим доступа: http://csrjournal.com/12931korporativnoe-grazhdan stvo-kaksostavlyayushhaya-ustojchivogo-razvitiyabiznesa-i-regiona.html (дата обращения: 10.01.2020). - Загл. с экрана.

Бондаренко, Т. И. Природа институциональных конфликтов в сфере «зеленого воспроизводства» экономики России / Т. И. Бондаренко, С. И. Мишулина // Пространственная и структурная трансформация экономики России: проблемы и перспективы : материалы Междунар. науч.-практ. конф. (г. Краснодар, 15-19 апр. 2019). - Краснодар : [б. и.], 2019. - С. 185-191.

Бриних, В. А. Во что сочинская Олимпиада обошлась природе? / В. А. Бриних // Астраханский вестник экологического образования. 2014. - № 2 (28). - C. 56-68.

ГОСТ Р 56548-2015/ISO/DIS/37101. Устойчивое развитие административно-территориальных образований. Системы менеджмента качества. Общие принципы // Электронный фонд правовой и нормативно-технической документации АО «Кодекс». - 2018. - Электрон. текстовые дан. - Режим доступа: https:// docs.cntd.ru/document/1200124250 (дата обращения: 22.01.2020). - Загл. с экрана.

ГОСТ Р ИСО 26000-2012. Руководство по социальной ответственности: Национальный стандарт Российской Федерации // Электронный фонд правовой и нормативно-технической документации АО «Кодекс». - 2018. - Электрон. текстовые дан. - Режим доступа: http://docs. cntd.ru/document/1200097847 (дата обращения: 22.01.2020). - Загл. с экрана.

Гришин, А. И. Социальное предпринимательство и социальные проекты бизнеса в рамках концепции устойчивого развития / А. И. Гришин, М. С. Мельников, И. А. Строганов // Вестник Академии. -2015. - № 1. - С. 9-15.

Губарева, Л. И. Экологическая ответственность фирмы и экономический успех / Л. И. Губарева, В. Н. Синельникова // Ученые записки Орловского государственного университета. Серия: Гуманитарные и социальные науки. 2011. - № 6. - С. 8-13.

Гудкова, Н. К. Риски загрязнения и истощения подземных вод при освоении уникальных природных комплексов долины реки Мзымта / Н. К. Гудкова // Устойчивое развитие особо охраняемых природных территорий : сб. ст. IV Всерос. науч.-практ. конф. - 2017. C. $107-112$.

Дегтярева, А. В. Важность зарубежного опыта в продвижении принципов корпоративной социальной ответственности в России / А. В. Дегтярева, В. О. Ядоян // Молодой ученый. - 2014. № 6. - С. 402-405.

Зайнашева, 3. Г. Особенности социальных предпринимателей и понятие социального предпринимательства / 3. Г. Зайнашева, Н. Г. Мешкова // Вестник УГНТУ. Наука, образование, экономика. Серия: Экономика. - 2018. - № 1 (23). C. $45-53$.

Иванов, А. А. Проблема экологической ответственности в современных юридических исследованиях / А.А. Иванов // Вестник ВУиТ. - 2015. № 4 (83). - Электрон. текстовые дан. - Режим доступа: https://cyberleninka.ru/article/n/ problema-ekologicheskoy-otvetstvennosti-vsovremennyh-yuridicheskih-issledovaniyah (дата обращения: 01.03.2020). - Загл. с экрана.

Лабаджян, М. Г. Понятие социальной ответственности бизнеса / М. Г. Лабаджян, А. Ю. Каспарова // Вестник ОмГУ. Серия: Экономика. 2014. - № 1. - С. 178-182.

Матвеева, Е. В. Корпоративное гражданство как философия социально ответственного бизнеса: новый уровень развития / Е. В. Матвеева // Актуальные проблемы экономики и права. - 2014. - № 2. - С. 49-54.

Матова, Н. И. Содержание понятия «зеленая» экономика в современных российских условиях / Н. И. Матова // Регионы России в новых экономических условиях : материалы науч.-практ. конф. - Сочи : [б. и.], 2016. - С. 66-75.

Матова, Н. И. Механизмы формирования экологически ответственного поведения бизнеса / Н. И. Матова // Системный подход к рациональному природопользованию регионов России : сб. ст. науч.-практ. конф. / под ред. С. Н. Цай, Д. Е. Яйли. - Краснодар : Юг, 2019a.- С. 67-71.

Матова, Н. И. Формы и направления взаимодействия социально-ответственного бизнеса и ООПТ / Н. И. Матова // Устойчивое развитие особо охраняемых природных территорий : сб. ст. VI Всерос. науч.-практ. конф. Сочи : Донской издательский центр Сочи: ГКУ КК «Природный орнитологический парк в Имеретинской низменности», 2019б. С. 195-202.

Минина, И. А. Сущность корпоративной социальной ответственности: правовой аспект / И. А. Ми- 
нина // Законодательство и экономика. - 2009. № 5. - С. 30-39.

Мишулина, С. И. Сущность «зеленого» туризма / С. И. Мишулина // Регионы России в новых экономических условиях : материалы науч.-практ. конф. - Сочи : СНИЦРАН, 2016. C. $75-84$.

Никифорова, О. А. Концепции социальной ответственности бизнеса: исходные понятия и классификации / О. А. Никифорова, Д. О. Митрофанова // Вестник Санкт-Петербургского унта. Серия 12, Социология. - 2017. - № 2. С. 214-228.

Нужина, И. П. Институционализация социальноэкологической ответственности строительного бизнеса / И. П. Нужина, М. В. Золотарева, Ю. В. Васильева // Современные технологии управления. - 2017. - № 11 (83) . C. $1-10$.

Рушева, А. В. Социальная ответственность бизнесрешений / А. В. Рушева // Вестник ПНИПУ. Социально-экономические науки. - 2019. № 1.-C. 85-99. - DOI: https://doi.org/10.15593/ 2224-9354/2019.1.8.

Туркин, С. Д. Зачем бизнесу социальная ответственность / С. Д. Туркин // Управление компанией. - 2004. - № 7. - Электрон. текстовые дан. Режим доступа: https://www.cfin.ru/press/ zhuk/2004-7/16.shtml?printversion. - Загл. с экрана.

Ускова, Т. В. Социальная ответственность бизнеса: состояние и инструменты развития / Т. В. Ускова, Е. Д. Копытова // Проблемы развития территории. - 2016. - № 6 (86). - С. 7-19.

Хорева, Л. В. История благотворительности в России / Л. В. Хорева, М. Д. Сущинская. - СПб. : СПбГУЭФ, 1999. - 92 с.

Хорева, Л. В. Новая концепция корпоративной социальной ответственности - КСО 2.0 / Л. В. Хорева, Я. В. Шокола // Теория и практика сервиса: экономика, социальная сфера, технологии. 2015. - № 4 (26) . - С. 25-30.

Ценностные основы социальной деятельности российского предпринимательства : аналитический обзор по результатам исследования. - М. : ГК Новард, 2015. - 77 с.

Porter, M. E. Creating Shared Value / M. E. Porter, M. R. Kramer // Harward Business Review (January / February). - 2011. - P. 62-77.

\section{REFERENCES}

Blagov Ju.E. Korporativnaya sotsialnaya otvetstvennost: evolyutsiya kontseptsii [Corporate Social Responsibility: The Evolution of the Concept]. Saint Petersburg, Vysshaya shkola menedzhmenta, 2011.272 p.

Blagov Ju.E. Ot CSR 1.0 k CSR 2.0. Sustainable Business [From CSR 1.0 to CSR 2.0. Sustainable Business]. URL: http://csrjournal.com/7077blagov-yuriy-evgenevich-ot-csr-10-k-csr20.html (accessed 9 February 2020).

Bozhko I. Korporativnoe grazhdanstvo kak sostavlyayushchaya ustoychivogo razvitiya biznesa i regiona [Corporate Citizenship as a Component of Sustainable Development of Business and the Region]. Ustoychivyy biznes [Sustainable Business], 2015, September 24. URL: http://csrjournal.com/12931-korporativnoegrazhdanstvo-kak-sostavlyayushhayaustojchivogo-razvitiya-biznesa-i-regiona.html (accessed 10 January 2020).

Bondarenko T.I., Mishulina S.I. Priroda institutsionalnykh konfliktov v sfere «zelenogo vosproizvodstva» ekonomiki Rossii [The Nature of Institutional Conflicts in the Sphere of "Green Reproduction" of the Russian Economy]. Prostranstvennaya $i$ strukturnaya transformatsiya ekonomiki Rossii: problemy $i$ perspektivy: materialy Mezhdunar. nauch.prakt. konf. (g. Krasnodar, 15-19 apr. 2019) [Spatial and Structural Transformation of the Russian Economy: Problems and Prospects. Proceedings of the International ScientificPractical Conference (Krasnodar, April 15-19, 2019)]. Krasnodar, [s. n.], 2019, pp. 185-191.

Brinih V.A. Vo chto sochinskaya Olimpiada oboshlas prirode? [What Did the Sochi Olympics Cost Nature?]. Astrakhanskiy vestnik ekologicheskogo obrazovaniya [Astrakhan Bulletin of Environmental Education], 2014, no. 2 (28), pp. 56-68.

GOST R 56548-2015/ISO/DIS/37101. Ustoychivoe razvitie administrativno-territorialnykh obrazovaniy. Sistemy menedzhmenta kachestva. Obshchie printsipy [Sustainable Development in Communities - Management System for Sustainable Development - Requirements with Guidance for Use]. Elektronnyy fond pravovoy i normativno-tekhnicheskoy dokumentatsii AO «Kodeks» [Electronic Fund of Legal and Normative-Technical Documentation AO "Kodeks"]. URL: http://docs.cntd.ru/document/ 1200124250 (accessed 22 January 2020).

GOST R ISO 26000-2012. Rukovodstvo po sotsialnoy otvetstvennosti: Natsionalnyy standart Rossiyskoy Federatsii [Guidance on Social Responsibility. National Standard of the Russian Federation]. Elektronnyy fond pravovoy $i$ normativno-tekhnicheskoy dokumentatsii AO «Kodeks»[Electronic Fund of Legal and 
Normative-Technical Documentation AO "Kodeks"].URL: http://docs.cntd.ru/document/ 1200097847 (accessed 22 January 2020).

Grishin A.I., Melnikov M.S., Stroganov I.A. Sotsialnoe predprinimatelstvo i sotsialnye proekty biznesa v ramkakh kontseptsii ustoychivogo razvitiya [Social Entrepreneurship and Social Business Projects in the Framework of the Concept of Sustainable Development]. Vestnik Akademii [Academy Herald], 2015, no. 1, pp. 9-15.

Gubareva L.I., Sinelnikova V.N. Ekologicheskaya otvetstvennost firmy i ekonomicheskiy uspekh [The Environmental Responsibility of the Company and Economic Success]. Uchenye zapiski Orlovskogo gosudarstvennogo universiteta. Seriya: Gumanitarnye i sotsialnye nauki [Scientific Notes of the Oryol State University. Series: Humanities and Social Sciences], 2011, no. 6, pp. 8-13.

Gudkova N.K. Riski zagryazneniya i istoshcheniya podzemnykh vod pri osvoenii unikalnykh prirodnykh kompleksov doliny reki Mzymta [Risks of Contamination and Depletion of Groundwater in the Development of Unique Natural Complexes of the Mzymta River Valley]. Ustoychivoe razvitie osobo ohranyaemykh prirodnykh territoriy: sb. st. VI Vseros. nauch.-prakt. konf. [Sustainable Development of Specially Protected Natural Territories. Proceedings of the VI Russian Scientific-Practical Conference], 2017 , pp. 107-112.

Degtjareva A.V., Jadojan V.O. Vazhnost zarubezhnogo opyta $\mathrm{v}$ prodvizhenii printsipov korporativnoy sotsialnoy otvetstvennosti v Rossii [Importance of Foreign Experience in Promoting the Principles of Corporate Social Responsibility in Russia]. Molodoy uchenyy [Young Scientist], 2014, no. 6, pp. 402-405.

Zajnasheva Z.G., Meshkova N.G. Osobennosti sotsialnykh predprinimateley i ponyatie sotsialnogo predprinimatelstva [Features of Social Entrepreneurs and the Concept of Social Entrepreneurship]. Vestnik UGNTU. Nauka, obrazovanie, ekonomika. Seriya: Ekonomika [Bulletin USPTU. Science, Education, Economy. Series Economy], 2018, no. 1 (23), pp. 45-53.

Ivanov A.A. Problema ekologicheskoy otvetstvennosti v sovremennykh yuridicheskikh issledovaniyakh [The Problem of Environmental Responsibility in Modern Legal Research]. Vestnik VUiT [Bulletin of VUiT], 2015, no. 4 (83). URL: https:// cyberleninka.ru/article/n/problemaekologicheskoy-otvetstvennost i-vsovremennyh-yuridicheskih-issledovaniyah (accessed 1 March 2020).
Labadzhjan M.G., Kasparova A.Ju. Ponyatie sotsialnoy otvetstvennosti biznesa [The Concept of Social Responsibility of Business]. Vestnik OmGU. Serija: Jekonomika [Herald of Omsk University. Series “Economics"], 2014, no. 1, pp. 178-182.

Matveeva E.V. Korporativnoe grazhdanstvo kak filosofiya sotsialno otvetstvennogo biznesa: novyy uroven razvitiya [Corporate Citizenship as a Philosophy of Socially Responsible Business: A New Level of Development]. Aktualnye problemy ekonomiki i prava [Actual Problems of Economics and Law], 2014, no. 2, pp. 49-54.

Matova N.I. Soderzhanie ponyatiya "zelenaya" ekonomika v sovremennykh rossiyskikh usloviyakh [The Content of the Concept of "Green" Economy in Modern Russian Conditions]. Regiony Rossii v novykh ekonomicheskikh usloviyakh: materialy nauch.-prakt. konf. [Regions of Russia in the New Economic Conditions. Proceedings of the Scientific and Practical Conference]. Sochi, [s. n.], 2016, pp. 66-75.

Matova, N. I. Mekhanizmy formirovaniya ekologicheski otvetstvennogo povedeniya biznesa [Mechanisms of the Formation of Environmentally Responsible Business Behavior]. Tsay S.N., Yayli D.E., eds. Sistemnyy podkhod $k$ ratsionalnomu prirodopolzovaniyu regionov Rossii: sb. st. nauch.-prakt. konf. [Systematic Approach to the Rational Use of Natural Resources in the Regions of Russia. Collection of Articles of the Scientific and Practical Conference.]. Krasnodar, Yug Publ., 2019a,pp. 67-71.

Matova N.I. Formy i napravleniya vzaimodeystviya sotsialno-otvetstvennogo biznesa i OOPT [Forms and Directions of Interaction of Socially Responsible Business and Protected Areas]. Ustoychivoe razvitie osobo okhranyaemykh prirodnykh territoriy: sb. st. VI Vseros. nauch.prakt. konf. [Sustainable Development of Specially Protected Natural Territories. Proceedings of the VI All-Russian Scientific and Practical Conference]. Sochi, Donskoy izdatelskiy tsentr Sochi, GKU KK «Prirodnyy ornitologicheskiy park V Imeretinskoy nizmennosti», 2019b, pp. 195-202.

Minina I.A. Sushchnost korporativnoy sotsialnoy otvetstvennosti: pravovoy aspect [Essence of Corporate Social Responsibility: Legal Aspect]. Zakonodatelstvo i ekonomika [Legislation and Economics], 2009, no. 5, pp. 30-39.

Mishulina S.I. Sushhnost "zelenogo" turizma [The Essence of Green Tourism]. Regiony Rossii v novykh ekonomicheskikh usloviyakh: materialy nauch.-prakt. konf. [Regions of Russia in the New 
Economic Conditions. Proceedings of the Scientific and Practical Conference]. Sochi, SNITs RAN, 2016, pp. 75-84.

Nikiforova O.A., Mitrofanova D.O. Kontseptsii sotsialnoy otvetstvennosti biznesa: iskhodnye ponyatiya i klassifikatsii [Concepts of Social Responsibility of Business: Initial Concepts and Classifications]. Vestnik Sankt-Peterburgskogo un-ta. Seriya 12, Sotsiologiya [Vestnik of Saint Petersburg University. Series 12, Sociology], 2017, no. 2, pp. 214-228.

Nuzhina I.P., Zolotareva M.V., Vasileva Ju.V. Institutsionalizatsiya sotsialno-ekologicheskoy otvetstvennosti stroitelnogo biznesa [Institutionalization of the Socio-Environmental Responsibility of the Construction Business]. Sovremennye tehnologii upravleniya [Modern Management Technologies], 2017, no. 11 (83), pp. 1-10.

Rusheva A.V. Sotsialnaya otvetstvennost biznesresheniy [Social Responsibility of Business Decisions]. Vestnik PNIPU. Sotsialnoekonomicheskie nauki [PNRPU Sociology and Economics Bulletin], 2019, no. 1, pp. 85-99. DOI: https://doi.org/10.15593/2224-9354/2019.1.8.

Turkin S.D. Zachem biznesu sotsialnaya otvetstvennost [Why Business Needs Social Responsibility]. Upravlenie kompaniey [Management of the Company], 2004, no. 7. URL: https://www.cfin.ru/press/zhuk/2004-7/16. shtml?printversion.

Uskova T.V., Kopytova E.D. Sotsialnaya otvetstvennost biznesa: sostoyanie i instrumenty razvitiya [Social Responsibility of Business: State and Development Tools]. Problemy razvitiya territorii [Problems of Territory Development], 2016, no. 6(86), pp. 7-19.

Horeva L.V., Sushhinskaja M.D. Istoriya blagotvoritelnosti $v$ Rossii [The History of Charity in Russia]. Saint Petersburg, SPbGUEF, $1999.92 \mathrm{p}$.

Horeva L.V., Shokola Ja.V. Novaya kontseptsiya korporativnoy sotsialnoy otvetstvennosti KSO 2.0 [New Concept of Corporate Social Responsibility - CSR 2.0]. Teoriya i praktika servisa: ekonomika, sotsialnaya sfera, tekhnologii [Theory and Practice of Service: Economics, Social Sphere, Technologies], 2015, no. 4 (26), pp. 25-30.

Tsennostnye osnovy sotsialnoy deyatelnosti rossiyskogo predprinimatelstva: analiticheskiy obzor po rezultatam issledovaniya [Value Bases of Social Activity of Russian Entrepreneurship:An Analytical Review Based on the Results of the Study]. Moscow, GK Novard Publ., 2015. 77 p.

Porter M.E., Kramer M.R. Creating Shared Value. Harward Business Review (January / February), 2011, pp. 62-77.

\section{Information About the Authors}

Natalya I. Matova, Candidate of Sciences (Economics), Senior Researcher, Laboratory of Environmental Economics and Ecology, Branch of Institute of Natural and Technical Systems, Prosp. Kurortnyy, 99/18, 354024 Sochi, Russian Federation, lelj06@yandex.ru, https://orcid.org/0000-0001-6084-6233

Svetlana I. Mishulina, Candidate of Sciences (Economics), Leading Researcher, Laboratory of Regional Economics, Sochi Scientific Research Center of the Russian Academy of Science, Teatralnaya St, 8A, 354000 Sochi, Russian Federation, MISHulSV@yandex.ru, https://orcid.org/0000-0003-0734-1791

\section{Информация об авторах}

Наталья Ивановна Матова, кандидат экономических наук, старший научный сотрудник лаборатории экономики природопользования и экологии, Институт природно-технических систем (филиал), просп. Курортный, 99/18, 354024 г. Сочи, Российская Федерация, lelj06@yandex.ru, https://orcid.org/0000-0001-6084-6233

Светлана Ивановна Мишулина, кандидат экономических наук, ведущий научный сотрудник лаборатории региональной экономики, Сочинский научно-исследовательский центр PAH, ул. Театральная, 8A, 354000 г. Сочи, Российская Федерация, MISHulSV@yandex.ru, https://orcid.org/0000-0003-0734-1791 